FINANCIAL: Jurnal Akuntansi

Published by Program Studi Akuntansi STIE Sultan Agung

Volume 7-Nomor 1, Juni 2021, (Hlm 69-75)

ISSN-P: 2502-4574, ISSN-E: 2686-2581

Available online at: https://financial.ac.id/index.php/financiaI

\title{
ANALISIS LAPORAN ARUS KAS UNTUK MENILAI KINERJA KEUANGAN PT. SEMEN BATURAJA (PERSERO), TBK YANG TERDAFTAR DI BURSA EFEK INDONESIA
}

\author{
Darwin Lie $^{1)}$, Ady Inrawan ${ }^{2)}$, Astuti ${ }^{3)}$, Kumala Sari ${ }^{4)}$ \\ ${ }^{1,2,3,4}$ Sekolah Tinggi Ilmu Ekonomi Sultan Agung, Jalan Surabaya No.19, Pematangsiantar, Sumatera \\ Utara, 21118, Indonesia \\ E-mail: ${ }^{1}$ darwin@ @stiesultanagung.ac.id, ${ }^{2}$ ady@ stiesultanagung.ac.id, ${ }^{3}$ astuti@ stiesultanagung.ac.id, \\ kmalas969@gmail.com
}

\begin{abstract}
Abstrak
Tujuan dari penelitian yaitu untuk mengetahui gambaran laporan arus kas dan kinerja keuangan serta mengetahui faktor yang menyebabkan kinerja keuangan PT Semen Baturaja (Persero), Tbk yang Terdaftar di Bursa Efek Indonesia. Metode analisis yang digunakan yaitu deskriptif kualittif, komparatif dan induktif. Jenis data yang digunakan adalah data kualitatif dan data kuantitatif. Sumber data merupakan data sekunder. Hasil penelitian disimpulkan bahwasanya keseluruhan dari hasil analisis rasio arus kas operasi (AKO), cakupan arus dana, cakupan kas terhadap bunga, cakupan kas terhadap hutang lancar, pengeluaran modal, total hutang, arus kas bersih bebas, kecukupan arus kas kinerja keuangan perusahaan sudah baik. Perusahaan dapat lebih meningkatan kinerja keuangan dengan cara melakukan perputaran kasnya agar dapat meningkatkan arus kas operasi yang diperoleh dari aktivitas operasi dan dapat melakukan pembayaran kewajiban lancar semakin cepat. Lebih memperhatikan lagi keadaan yang lebih baik saat akan melakukan pinjaman kepada pihak yang berkepentingan agar arus kas operasi yang dihasilkan dari aktivitas operasi bisa disesuaikan untuk memenuhi kewajiban perusahaan saat operasi.
\end{abstract}

Kata kunci: Laporan Arus Kas, Kinerja Keuangan

\section{ANALYSIS OF CASH FLOW STATEMENT TO VALUE THE FINANCIAL PERFORMANCE OF PT SEMEN BATURAJA (PERSERO), TBK ON THE INDONESIAN EXCHANGE}

\begin{abstract}
The purpose of this research is to find out the description of the cash flow statement, financial performance and to analyze the factors that cause the financial performance of PT Semen Baturaja (Persero), Tbk which is listed on the Indonesia Stock Exchange. The analytical method used is descriptive qualitative, comparative and inductive. The types of data used are qualitative and quantitative data. The data source is secondary data. The results of the study concluded that the overall results of the analysis of operating cash flow ratios, fund flow coverage, cash coverage to interest, cash coverage to current liabilities, capital expenditures, total debt, free net cash flow, cash flow adequacy, the company's financial performance was good. Companies can further improve financial performance by making cash turnover in order to increase operating cash flow obtained from operating activities and can make payments of current liabilities faster. Paying more attention to better conditions when making loans to interested parties so that operating cash flows generated from operating activities can be adjusted to meet the company's obligations during operations.
\end{abstract}

Keywords : Cash flow report, Financial Performance.

Article History: Received: 10 Apr 2021 Revised: 08 Mei 2021 Accepted: 20 Mei 2021 


\section{PENDAHULUAN}

Dalam perkembangan dunia usaha, bidang keuangan menjadi bidang yang sangat penting. Perusahaan harus men-cermati dan menganalisa kinerja keuangan agar tetap bertahan, salah satunya dengan cara menganalisa kinerja terhadap laporan keuangan. Kinerja keuangan ialah prospek pertumbuhan dan potensi perkembangan yang baik. Salah satu cara mengukur tingkat kinerja keuangan yaitu dengan menganalisis laporan arus kas. Analisis laporan aruskas yaitu analisa keuangan untuk manajer disamping keuangan lainnya. Laporan arus kas menyediakan informasi yang mempermudah pengguna laporan untuk menilai pengaruh aktivitas terhadap posisi keuangan dan jumlah kas dan setara kas.

Melalui analisis arus kas dapat dinilai kemungkinan perusahaan dalam menghasilkan kas dimasa yang akan datang dan kemampuan perusahaan untuk membayar kewajiban jangka pendek maupun jangka panjang, deviden kepada para pemegang saham, serta dapat pula menilai apakah investasi perusahaan memberikan arus kas dan return yang baik bagi perusahaan (Siahaan, 2017). Analisis laporan arus kas berguna untuk mengevaluasi posisi dan operasi perusahaan dengan melakukan perbandingan dari tahun-tahun sebelumnya sehingga dapat diketahui baik tidaknya kinerja perusahaan dalam beroperasi (Warongan \& Gerungai, 2018).

Dalam penelitian ini, penulis mengukur arus kas dengan merujuk pada Darsono dan Ashari (2005:91) yang terdiri dari delapan rasio, yaitu rasio Arus Kas Operasi (AKO), rasio Cakupan Arus Dana (CAD) yaitu kemampuan menghasilkan kas untuk memenuhi komitmen, rasio Cakupan Kas terhadap Bunga (CKB) yaitu pembayaran bunga atas hutang, rasio
Cakupan Kas terhadap Hutang Lancar (CKHL) yaitu pembayaran hutang lancar atas AKO bersih, rasio Pengeluaran Modal (PM) yaitu pemenuhan hutang dan mengukur modal tersedia untuk investasi, rasio Total Hutang (TH) yaitu pemenuhan hutang dengan AKO, rasio Arus Kas Bebas (AKBB) yaitu pembayaran kewajiban kas dimasa mendatang dan rasio Kecukupan Arus Kas (KAK) yaitu pemenuhan kas untuk menutupi kewajibannya dalam 5 tahun kedepan.

Objek penelitian adalah PT Semen Baturaja (Persero), Tbk. Data gambaran rasio AKO, CAD, CKB, CKHL, PM, TH, AKBB, dan KAK dapat dilihat pada Tabel 1.1 dibawah ini:

\section{Tabel 1. Gambaran Rasio Arus Kas} PT Semen Baturaja. Tbk

\begin{tabular}{|c|c|c|c|c|c|c|c|c|}
\hline \multirow{2}{*}{ Ket } & \multicolumn{7}{|c|}{ Thun } & \multirow{2}{*}{$\begin{array}{l}\text { Rath } \\
\text { rath }\end{array}$} \\
\hline & 2012 & 2013 & 2014 & 2015 & 2016 & 2917 & 2018 & \\
\hline AKO & 2,55 & 154 & 1,58 & 2.04 & 0,30 & 0.27 & 0,10 & 1,20 \\
\hline CAD & \$992.1 & 4630,48 & $15 \% 0,7$ & 2141,8 & 576,23 & 25497 & 25,02 & 261,3 \\
\hline CKB & 68847 & 6276,94 & 22491 & 3800 & 26,15 & 30639 & 13,27 & उol92, \\
\hline CKHL & 2,58 & 1,85 & 201 & 2,36 & 0,60 & 037 & 0,16 & 1,42 \\
\hline PM & 1,35 & 2,15 & 891 & 16,85 & 309 & 5,12 & 0,33 & 5,40 \\
\hline TH & 1,79 & 1,22 & 1,36 & 1,64 & 0,07 & 0.11 & 0,03 & 0,8 \\
\hline AK6B & 0.28 & 459 & 1269 & 639 & 0,33 & 0,18 & 605 & 3,41 \\
\hline KAK & 0,15 & 0.26 & 8.41 & 0,67 & 0,64 & $\sqrt{31}$ & 0.05 & 0,31 \\
\hline
\end{tabular}

Sumber: Laporan Keuangan (Diolah Peneliti, 2020)

Pada data Tabel 1.1. terlihat rasio AKO yang digunakan mengalami penurunan, dengan rata-rata $\mathrm{Rp}$ 1,20. Rasio $\mathrm{CAD}$ mengalami penurunan, dengan rata-rata $\mathrm{Rp}$ 2167,35. Rasio CKB mengalami penurunan, dengan rata-rata Rp 3092,79. Rasio CKHL mengalami penurunan, dengan rata-rata $\mathrm{Rp}$ 1,42. Rasio PM mengalami penurunan, dengan rata-rata $\mathrm{Rp} 5,40$. Rasio $\mathrm{TH}$ mengalami penurunan, dengan rata-rata $\mathrm{Rp}$ 0,89 . Rasio AKBB mengalami penurunan dengan rata-rata $\mathrm{Rp} 3,41$, serta rasio KAK mengalami peningkatan dengan rata-rata 0,31 . Sehingga adanya temuan untuk 
keseluruhan rasio pada PT. Semen Baturaja, Tbk cenderung menurun namun rata-rata kinerja keuangan berada di atas 1 memperlihatkan kondisi kinerja keuangan PT. Semen Baturaja, Tbk dalam keadaan baik.

\section{LANDASAN TEORI}

Kinerja keuangan merupakan analisis yang dilakukan untuk mengetahui sejauh mana pelaksanaan perusahaan menggunakan aturan-aturan keuangan secara baik dan benar (Fahmi, 2014:239). Pengukuran kinerja keuangan ini bertujuan untuk mengevaluasi efisien dan menghasilkan laba dan posisi kas (Hery, 2014:25). Brigham dan Joel (2012:99) mengemukakan tujuan dari laporan arus kas yaitu melaporkan peneriman kas, pembayaran, dan perubahan bersih kegiatan operasional, investasi dalam merekonsilasi saldo kas awal danakhir. Tujuan penyusunan laporan arus kas juga memberikan informasi tentang jumlah kas yang diperoleh dari kegiatan operasi, investasi, serta pendanaan dan kenaikan atau penurunan bersih kas selama periode waktu tertentu (Giri, 2017). Menurut Darsono dan Ashari (2005:91) penilaian arus kas mengunakan rasio-rasio keuangan dapat dirumuskan sebagai berikut:

1. Rasio Arus Kas Operasi (AKO)

Arus Kas Operasi

Kewajiban Lancar

2. Rasio Cakupan Arus Dana (CAD) EBIT

Bunga+Penyesuaian Pajak+Dividen Preferen

3. Rasio Cakupan Kas Terhadap Bunga $(\mathrm{CKB})$

Rasio Arus Kas Operasi + Bunga+Pajak Bunga
4. Rasio Cakupan Kas Terhadap Hutang Lancar (CKHL)

ArusKasOperasi + Dividenkas

HutangLancar

5. Rasio Pengeluaran Modal (PM)

$$
\frac{\text { ArusKas Operasi }}{\text { Pengeluaran Modal }}
$$

6. Rasio Total Hutang (TH)

$$
\frac{\text { Arus Kas Operasi }}{\text { Total Hutang }}
$$

7. Rasio Arus Kas Bebas (AKBB)

Laba Bersih + Bunga + Depresiasi + Sewa +

Laesing + Dividen - Pengmodal + Sewa

Biaya Bunga + Sewa + Hutang Jangka Panjang

+ Kewajiban Laesing

8. Rasio Kecukupan Arus Kas (KAK)

$$
\frac{\text { EBIT-Bunga-Pajak-PengModal }}{\text { Rataan hutang lancar selama } 5 \text { thn }}
$$

Berdasarkan gambaran, definisi serta temuan sebelumnya dapat dilihat adanya hubungan laporan arus kas dengan kinerja keuangan yaitu saat rasio AKO diatas 1, mengindikasikan kemampuan membayar kewajiban lancar, tanpa memakai arus kas, rasio CAD mengindikasikan kemampuan yang lebih baik dari EBIT dalam memenuhi komitmennya, rasio CKB kemampuan yang lebih baik dalam memenuhi biaya bunga, rasio CKHL, kemampuan dalam membayar hutang lancar semakin baik, rasio PM menggambarkan kemampuan yang rendah menunjukkan kemampuan dari arus kas dalam membiayai pengeluaran modal, rasio TH menggambarkan kemampuan yang kurang baik dalam membayar kewajibanya dari arus kas yang berasal dari $\mathrm{AKBB}$ menggambarkan kemampuan dalam 
menutupi kewajiban kas dengan AKO serta rasio KAK menggambarkan kemampuan penyediaan kas agar memenuhi kewajibannya dalam waktu 5 tahun kedepan.

\section{METODE}

Penelitian ini menggunakan desain penelitian kepustakaan, data diperoleh adalah data sekunder dengan mengakses www.idx.co.id serta metode dokumentasi, deskriptif kualitatif dan kuantitatif. Objek penelitian PT. Semen Baturaja (Persero), Tbk yang terdaftar di Bursa Efek Indonesia dengan tahun penelitian 2012-2018.

\section{HASIL DAN PEMBAHASAN}

Analisis Rasio AKO

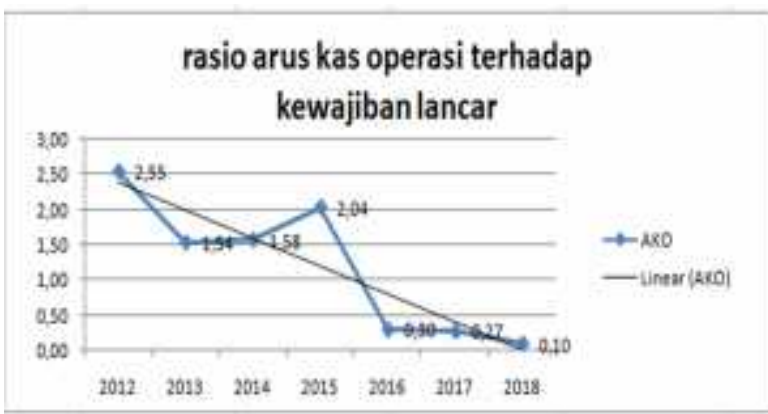

Sumber: Diolah Peneliti (2020)

Gambar 1. Grafik AKO

Berdasarkan grafik, dapat dilihat rasio AKO berfluktuasi cenderung menurun. AKO mengalami penurunan yang berasal dari pembayaran kas kepada pemasok dan karyawan yang diikuti dengan jumlah kewajiban lancar yang meningkat yang berasal dari utang usaha pihak ketiga, dan utang pajak. Pada tahun 2016-2018 terlihat bahwa nilai AKO dibawah 1 yang berarti pada tahun-tahun tersebut PT. Semen Baturaja, Tbk masih belum mampu untuk menutup kewajiban lancarnya dengan menggunakan arus kas operasi yang dimiliki, sehingga perusahaan harus meningkatkan lagi penerimaan kas kepada pelanggan agar kas tetap meningkat dan dapat melunasi kewajiban lancar secara optimal.

Copyright (C) 2021, FINANCIAL: Jurnal Akuntansi

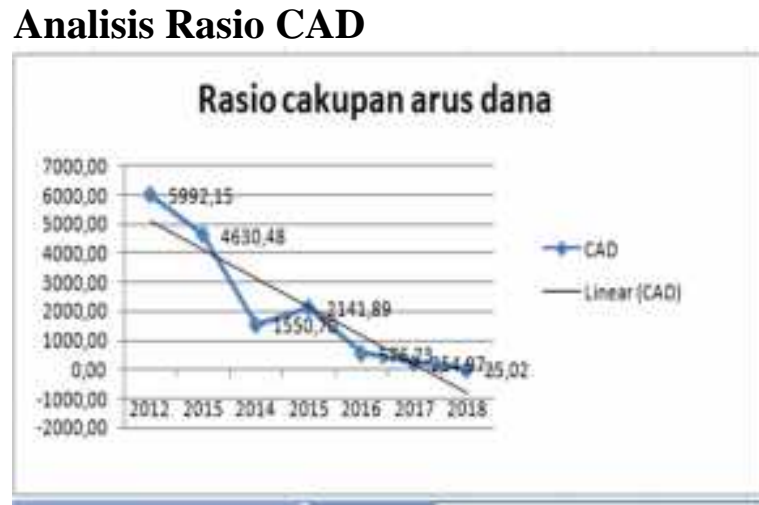

Sumber: Diolah Peneliti (2020)

Gambar 2. Grafik CAD

Berdasarkan grafik, dapat dilihat rasio CAD berfluktuasi cenderung menurun. Kondisi ini disebabkan karena EBIT mengalami penurunan diikuti dengan bunga sehingga tidak mampu menutupi biaya-biaya pada perusahaannya. Untuk itu sebaiknya perusahaan lebih meningkatkan lagi penjualannya kepada pelanggan agar dapat melakukan pembayaran pajak dan bunga.

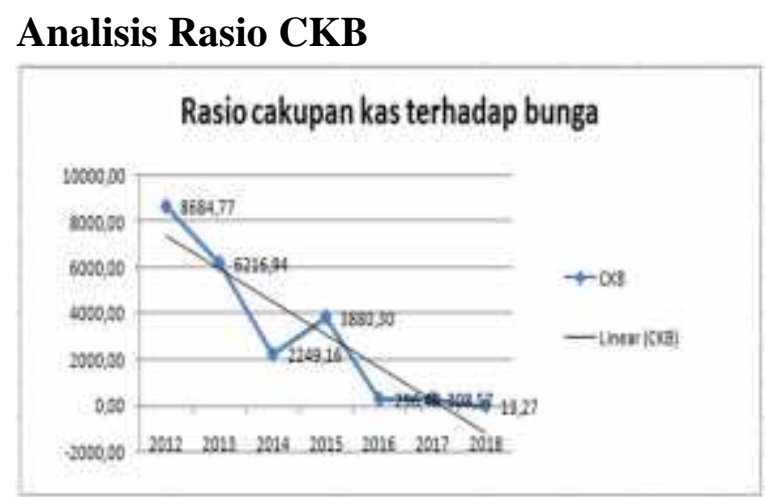

Sumber: Diolah Peneliti (2020) Gambar 3. Grafik CKB

Rasio CKB berfluktuasi cenderung menurun. Hal ini disebabkan karena nilai arus kas operasi mengalami penurunan yang berasal dari pembayaran kas kepada pemasok dan diikuti dengan bunga dan pajak. Untuk itu sebaiknya perusahaan meningkatkan lagi laba yang berasal dari penerimaan kas dari pelanggan. 
Analisis Rasio CKHL

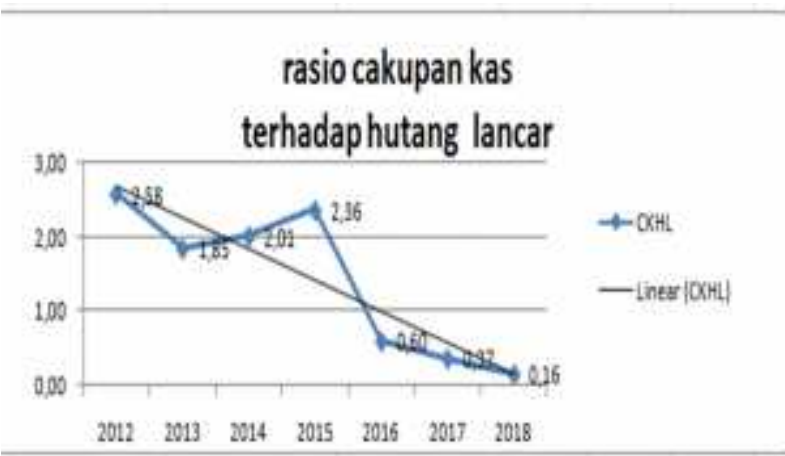

Sumber: Diolah Peneliti (2020)

Gambar 4. Grafik CKHL

Rasio CKHL berfluktuasi cenderung menurun yang disebabkan arus kas operasi berasal dari pembayaran kas kepada pemasok dan karyawan diikuti deviden dan hutang lancer berasal dari utang usaha pihak ketiga dan utang pajak. Sebaiknya meningkatkan AKO dari penerimaan kas dari pelanggan agar dapat melunasi hutang lancernya.

\section{Analisis Rasio PM}

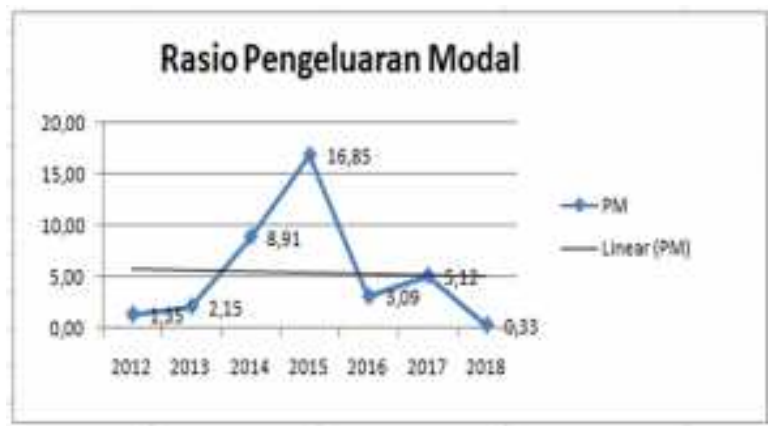

Sumber: Diolah Peneliti (2020)

\section{Gambar 5. Grafik PM}

Rasio PM berfluktuasi cenderung meningkatan yang berasal dari penerimaan kas kepada pelanggan, sedangkan pengeluaran modal mengalami penurunan. Sebaiknya lebih meningkatkan lagi jumlah arus kas operasi agar ditahun-tahun yang akan datang perusahaan mampu membiayai pengeluaran modalnya.

Copyright (C) 2021, FINANCIAL: Jurnal Akuntansi

\section{Analisis Rasio TH}

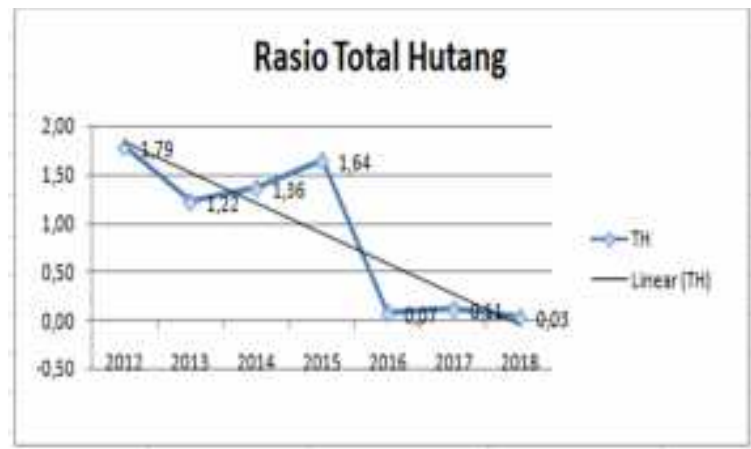

Sumber: Diolah Peneliti (2020)

Gambar 6. Grafik TH

Rasio berfluktuasi cenderung menurun. Hal ini dikarenakan AKO yang mengalami penurunan yang berasal dari pembayaran kas kepada pemasok dan karyawan dengan total hutang yang meningkat. Sebaiknya meningkatkan penjualan kepada pelanggan sehingga dapat meningkatkan kas yang mampu melunasi kewajiban dan sebaiknya memanfaatkan secara optimal untuk memperoleh laba serta meningkatkan AKO dari penerimaan pelanggan.

\section{Analisis Rasio AKBB}

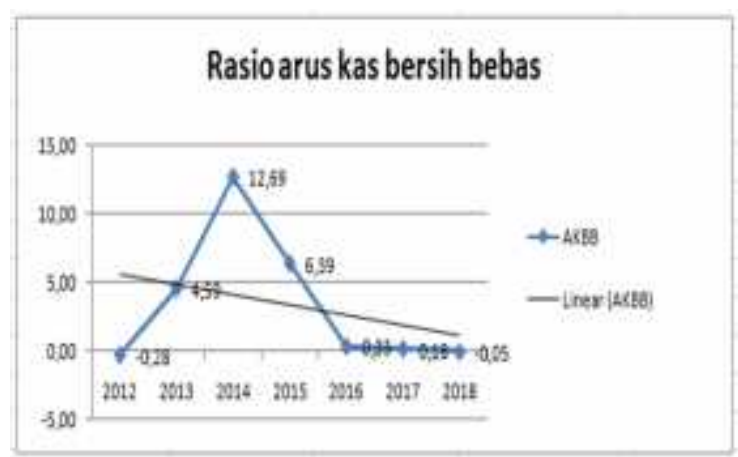

Sumber: Diolah Peneliti (2020)

Gambar 7. Grafik AKBB

Rasio AKBB berfluktuasi cenderung menurun. Hal ini disebabkan laba bersih dan pengeluaran modal yang menurun, sedangkan pembayaran bunga dan deviden meningkat diikuti dengan hutang jangka panjang yang berasal dari hutang bank dan 
utang sewa. Sebaiknya meningkatkan penjualan kepada pelanggan dan memperhatikan pengeluaran modal serta kewajiban lancer agar dapat menyediakan kas untuk memenuhi kewajiban dengan AKO.

\section{Analisis Rasio KAK}

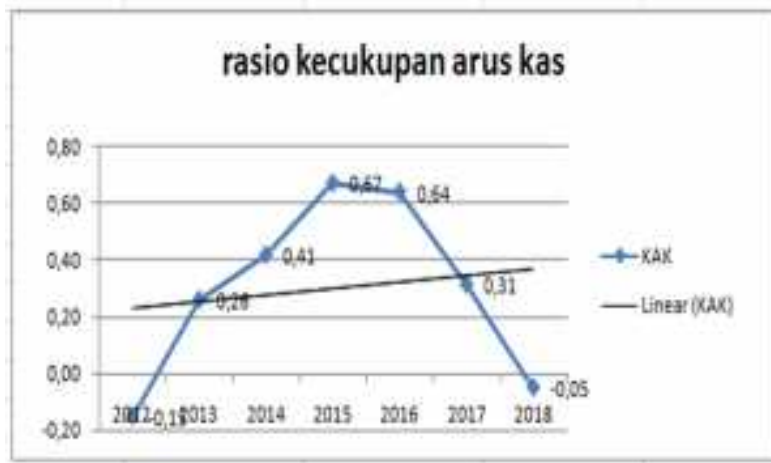

Sumber: Diolah Peneliti (2020)

Gambar 8. Grafik KAK

Rasio KAK berfluktuasi cenderung menurun. Penurunan ini disebabkan karena EBIT mengalami penurunan sedangkan bunga dan pengeluaran modal mengalami penurunan. Sebaiknya meningkatkan labanya lagi agar dapat memenuhi pembayaran bunga dan pajak dan memanfaatkan pengeluaran modal dengan baik.

\section{Rasio Arus Kas Operasi Sebagai Alat Ukur Kinerja}

Berdasarkan analisis rasio arus kas untuk mengukur kinerja keuangan PT Semen Baturaja (Persero), diketahui bahwasanya rasio arus kas menunjukkan kondisi keuangan kurang baik, karena dari 8 rasio yang diperhitungkan seluruhnya menunjukkan tren yang cenderung menu-run, maka kinerja keuangan selama 7 (tujuh) tahun cenderung menurun.

\section{KESIMPULAN DAN SARAN \\ Kesimpulan}

Rasio AKO berfluktuasi cenderung menurun. Penurunan AKO mengalami penurunan yang berasal dari pembayaran kas kepada pemasok dan karyawan yang diikuti dengan jumlah kewajiban lancar yang meningkat yang berasal dari utang usaha pihak ketiga, dan utang pajak. Rasio CAD berfluktuasi cenderung menurun. Hal ini disebabkan karena EBIT mengalami penurunan diikuti dengan bunga sehingga tidak mampu menutupi biaya-biaya. Rasio CKB berfluktuasi cenderung menurun. Hal ini disebabkan karena nilai arus kas operasi mengalami penurunan yang berasal Pembayaran kas kepada pemasok serta diikuti dengan bunga dan pajak. Rasio CKHL berfluktuasi cenderung menurun. Hal ini disebabkan arus kas operasi berasal dari pembayaran kas kepada pemasok dan karyawan diikuti deviden dan hutang lancer berasal dari utang usaha pihak ketiga dan utang pajak. Rasio PM berfluktuasi cenderung meningkatan yang berasal dari penerimaan kas kepada pelanggan, sedangkan penge-luaran modal mengalami penurunan. Rasio berfluktuasi cenderung menurun. Hal ini dikarenakan AKO yang mengalami penurunan yang berasal dari pembayaran kas kepada pemasok dan karyawan dengan total hutang yang meningkat. Rasio AKBB berfluktuasi cenderung menurun. Hal ini disebabkan laba bersih dan pengeluaran modal yang menurun, sedangkan pembayaran bunga dan deviden meningkat diikuti dengan hutang jangka panjang yang berasal dari hutang bank dan utang sewa. Rasio KAK berfluktuasi cenderung menurun. Penurunan ini disebabkan karena EBIT mengalami penurunan sedangkan bunga dan pengeluaran modal mengalami penurunan. 


\section{Saran}

Untuk meningkatkan rasio $\mathrm{AKO}$, Sebaiknya, meningkatkan lagi penerimaan kas kepada pelanggan agar kas tetap meningkat dapat melunasi kewajiban lancar secara optimal. Untuk meningkatkan rasio CAD, sebaiknya meningkatkan lagi penjualan kepada pelanggan agar melakukan pembayaran pajak dan bunga. Untuk meningkatkan rasio $\mathrm{CKB}$, sebaiknya meningkat-kan lagi laba yang berasal dari penerimaan kas dari pelanggan. Untuk meningkatkan Rasio CKHL, Sebaiknya meningkatkan AKO dari penerimaan kas dari pelanggan agar dapat melunasi hutang lancernya. Untuk meningkatkan rasio PM, Sebaiknya meningkatkan penjualan kepada pelanggan sehingga dapat meningkatkan kas yang mampu melunasi kewajiban dan sebaiknya memanfaatkan secara optimal untuk memperoleh laba serta meningkatkan AKO dari penerimaan pela-nggan. Untuk meningkatkan rasio $\mathrm{TH}$, Sebaiknya meningkatkan penjualan kepada pelanggan dan memperhatikan pengeluaran modal serta kewajiban lancer agar dapat menyediakan kas untuk memenuhi kewajiban dengan AKO. Untuk meningkatkan rasio AKBB, Sebaiknya meningkatkan penjualan kepada pelanggan dan memperhatikan pengeluaran modal serta kewajiban agar menyediakan kas untuk meme- nuhi kewajiban dengan AKO. Untuk meningkatkan rasio KAK, Sebaiknya meningkatkan labanya lagi agar dapat memenuhi pembayaran bunga dan pajak dan memanfaatkan pengeluaran modal dengan baik.
DAFTAR PUSTAKA

Brigham, Eugene F dan Joel F Houston. 2012. Dasar-dasar Manajemen Keuangan. Buku 2. Edisi XI. Jakarta: Salemba Empat.

Darsono dan Ashari. 2005. Pedoman Praktis Memahami Laporan Keuangan. Yogyakarta: CV Andi Ofset.

Fahmi, Irham. 2014. Analisis Kinerja Keuangan. Alfabeta. Bandung.

Giri, E. F. 2017. Akuntansi Keuangan Menengah 1 Perspektif PSAK dan IFRS. Edisi 2. Yogyakarta: UPP STIM YKPN.

Hery. 2009. Teori Akuntansi. Edisi 1 Cetakan Pertama. Jakarta: Prenada Media Group.

Siahaan, D. 2017. Analisis Laporan Arus Kas untuk Menilai Kinerja Keuangan pada Koperasi Kredit Sejahtera (Credit Union) Tanjung Marulak Kec. Rambutan Kota Tebing Tinggi.

Warongan, M. S. J., Ilat, V., \& Gerungai, N. 2018. Analisis Rasio Arus Kas Dalam Menilai Kinerja Keuangan Pada PT. PLN (Persero) Wilayah Suluttenggo. Jurnal Riset Akuntansi Going Concern, 13(02) 